\title{
Effectiveness of Global Postural Reeducation Compared to Segmental Stretching on Pain, Disability, and QOL of Subjects with Neck and Shoulder Pain
}

Hochung Jeon', Giwon Kim ${ }^{2,3}$

'Major in Rehabilitation Science, Department of Public Health Science, Korea University Graduate School, Seoul; ${ }^{2}$ Department of Physical Therapy, College of Health Science, Korea University, Seoul; ${ }^{3}$ Research Institute of Health Sciences, Korea University, Seoul, Korea

Purpose: This randomized controlled trial was conducted to compare the effectiveness of global postural reeducation to segmental stretching in subjects with neck and shoulder pain.

Methods: Sixteen subjects with neck and shoulder pain were randomized into two intervention groups, a global posture reeducation group $(n=8)$ that performed muscle chain stretching, and a segmental stretching group $(n=8)$ that performed conventional static muscle stretching. The intervention program consisted of two 40 minutes individual sessions per week for four weeks. Subjects were evaluated pre-intervention, two-week after intervention and at a four-week follow-up appointment for pain intensity, disability and health-related quality of life. Two-way repeated analysis of variance was used for between-time and between-group comparisons. The significance level was 0.05 .

Results: Significant pain relief and decreasing discomfort of the neck and shoulder were observed after intervention in both groups, and there was an interaction between time lapse and groups (pain, $F=10.31$, neck disability, $F=25.45$, shoulder disability, $F=12.82, p<0.05$ ). Quality of life also improved after intervention in both groups. Moreover, the physical components score improved, and a significant interaction was observed between time and groups $(F=4.85, p<0.05)$. However, no significant improvement in mental component score of quality of life and no significant interaction between time and groups were observed ( $p>0.05)$.

Conclusion: These findings suggest that a GPR intervention in subjects with neck and shoulder pain induces greater improvement of pain and disability and quality of life than segmental stretching.

Keywords: Muscle stretching exercise, Neck pain, Quality of life, Shoulder pain

서 론

목과 어깨는 많은 사람들이 통증을 호소하는 부위이다. 장시간 컴퓨 터를 사용하거나 과도한 스마트 기기의 사용, 잘못된 수면습관, 자세 유지를 위한 근육의 약화 등은 비정상적인 자세를 야기시킨다.1,2 예 를 들면, 현대인의 작업 환경을 대표할 수 있는 전방 머리자세는 단축 된 앞쪽 목 근육이 뒤쪽 목 근육을 과도하게 늘리는데, 이는 자세 유 지를 위한 근육을 긴장시키고 정상적인 기능을 하지 못하게 만든다. 둥근 어깨자세는 위팔어깨관절과 어깨뼈를 정상보다 멀어지게 만든 다. 이 자세는 어깨뼈에 붙어있는 많은 근육들을 당겨서 긴장시키고 경련을 만들어내기도 하며, 이와 같은 자세의 변화는 목과 어깨의 자

Received Jan 9, 2017 Revised Feb 15, 2017

Accepted Feb 28, 2017

Corresponding author Giwon Kim

E-mail rldnjs44@korea.ac.kr
세 유지를 위한 근육을 약화시키고, 통증과 기능장애를 일으킨다. ${ }^{4}$ 특히 요즘은 핸드폰과 휴대형 컴퓨터의 사용이 늘어나 통증, 자세 불 균형, 기능 장애 등이 일상 생활과 업무에 밀접한 영향을 미친다. ${ }^{5}$ 만 석정인 목과 어깨의 통증과 불편감은 낮은 직무능력과 함께 삶의 질 까지 감소시킨다. ${ }^{6}$

목과 어깨 통증과 기능 장애에 대한 치료는 심각한 손상으로 인해 수술적인 방법이 반드시 필요한 경우를 제외하고 대부분 약물, 물리 치료, 운동치료, 스트레칭 등 보존적인 치료를 적용한다.-10 이 치료 방법들 중 스트레칭은 연부조직의 저가동성과 단축된 근골격계 구 조의 가동범위를 증가시키는 데 사용되는 일반적인 운동 기법으로, ${ }^{11}$ 근육의 뺏뻣함(muscle stiffness)으로 인해 줄어든 가동범위의 증가와

Copylight (C2017 The Korea Society of Physical Therapy

This is an Open Access article distribute under the terms of the Creative Commons Attribution Non-commercial License (Http:// creativecommons.org/license/by-nc/4.o.) which permits unrestricted non-commercial use, distribution, and reproduction in any medium, provided the original work is properly cited. 
통증 감소를 목적으로 한다.12,13 스트레칭 기법으로는 정적 스트레칭 과 동적 스트레칭, 고유수용성 신경근 촉진법(proprioceptive neuromuscular facilitation, PNF)의 유지이완(hold-relax, HR), 주동근 수축, 등척성 수축 후 스트레칭 그리고 길항근 등척성 수축을 유도하는 방 법 등이 있다..$^{14}$

여러 가지 스트레칭 기법들 중 정적, 동적 스트레칭은 인체의 움직 임이 일어나는 각 관절 분절을 중심으로 이루어지는 분절적 스트레 칭 기법이며 가장 보편적인 방법이다. 그러나 인체의 근육은 다른 근 육들과 서로 연결되어 있어 한 근육을 신장하면 근접한 다른 근육들 에게도 영향을 미친다. 따라서 최근에는 신체 한 부분의 근육 활동이 연결된 근육을 따라 다른 신체 부위의 근육활동을 야기시키는 방산 (irradiation) 효과를 이용한 PNF 기법이 가동범위 증진에 더 효과적 이라는 연구들도 있다. ${ }^{15}$ 최근 유럽에서 시작된 새로운 스트레칭 기법 인 포괄적 자세 재교육(global postural reeducation, GPR)은 해부학, 생 체역학, 운동학, 정골요법 등에 대한 지식을 바탕으로 만들어진 방법 이다. ${ }^{16} \mathrm{GPR}$ 은 근육사슬(muscle chain) 이론을 중점으로 근육계를 통 합적인 시각으로 보고 있다. 근육의 물리적 특성에 중점을 둔 기존의 이론과 달리, 근육사슬이 체질, 행동, 심리적 요소 등에 의해 변할 수 있다는 사고를 기반으로 하는 GPR의 목표는 조직의 점성과 탄성을 이용하여 단축된 근육을 이완시키고 길항근을 강화시키는 것이 다. ${ }^{17,18}$ 기존의 스트레칭은 하나의 근육이나 근육들을 한계치까지 스 트레칭한 후 30 초 정도를 유지하는데, 이와 같은 방법은 적절하게 수 행하지 않았을 때 효과가 없거나 해로울 수 있다. 심지어 근육이 찢어 지거나 관절에 과운동성, 불안정성이 생길 수 있고, 심한 경우에는 근 섬유, 인대, 힘줄에 영구적인 손상이 생길 수 있다. ${ }^{19}$ 반면, GPR은 항중 력근을 전체적으로 스트레칭 하는데, 근육사슬로 연결되어 있는 근 육들을 앞쪽과 뒤쪽으로 구분하여 20 분 정도 스트레칭한다..$^{20}$ 이와 같은 방식은 기존의 스트레칭 방법보다 근육, 인대, 힘줄 등에 생길 수 있는 손상과 그로 인한 부작용이 적다. ${ }^{21}$

$\mathrm{GPR}$ 을 이용한 선행 연구들은 GPR과 정적 스트레칭을 비교하여 만성 목통증과 허리통증, 턱관절 통증, 경직성 척추염, 요실금 환자에 게 GPR이 효과적인 스트레칭 기법임을 증명하였다. ${ }^{20-26}$ 그러나 최근 발표된 체계적 고찰에 의하면 통증 감소 효과는 아무것도 안 하는 것 에 비해서는 효과가 좋지만 분절적 스트레칭이나 다른 치료에 비해 효과적이라 할 수 없고 강직성 척추염의 기능적 능력 증진에는 효과 적이지만 질병 활동력을 감소시키는 데 효과적이지 않다고 결론지었 다. ${ }^{27}$ 이러한 결과를 도출한 근거들은 낮거나 매우 낮은 근거의 질 수 준으로 해석에 주의를 해야 하며 앞으로의 연구는 높은 질 수준의 근 거를 마련해야한다.

따라서 본 연구에서는 대표적인 정적 스트레칭인 분절적 스트레칭 (segmental stretching, SS)과 GPR을 비교하여 목과 어깨에 통증이 있
는 사람을 대상으로 서로 다른 두 스트레칭 방법이 통증과 기능 장 애, 삶의 질에 어떤 영향을 미치는지 알아보고자 하였다.

\section{연구 방법}

\section{1. 연구대상}

본 연구 대상자의 포함기준은 18 세 이상 성인 중 자각증상으로 목과 어깨에 통증을 느끼거나 통증으로 인해 일상생활에서 불편함이 느 껴지는 사람으로 하였다. 대상자의 제외기준은 1) 최근 1 년 이내 목과 어깨의 수술 경험이 있는 자, 2) 현재 경추관 협착증 진단을 받은 자, 3) 현재 척수병증 진단을 받은 자, 4) 현재 추간판 탈출증 진단을 받은 자, 5) 현재 긴가슴신경 혹은 척수부신경의 병변으로 인한 날개견갑 증후군 진단을 받은 자이다.

대상자들은 K대학교 기관생명윤리위원회의 승인 이후 게시판에 공고를 통해 자발적으로 실험에 참여하기를 원하는 사람들을 연속 표본으로 모집하였다. 연구에 필요한 대상자 수는 $\mathrm{G}^{*}$ power 3.1 프로 그램을 이용하여 Silva 등 ${ }^{28}$ 의 연구를 바탕으로 검정력 0.8 , 유의수준 0.05 , 효과크기 1.60 으로 하였을 때 각 그룹당 8 명씩 총 16 명으로 계산 하였다.

총 16 명의 대상자가 자발적으로 모집되었고 모집 대상자들에게 1-16까지의 번호를 배정하고 엑셀의 무작위수 생성함수를 이용하여 8명씩 실험군과 대조군으로 배정하였다. 실험군은 GPR 중재를 받았 고 대조군은 SS 중재를 받았다. 대상자들은 연구에 대한 충분한 설명 을 듣고 동의서를 작성한 후 실험에 참여하였다. 연구 대상자의 일반 적인 특성과 임상 특성은 Table 1에 제시하였다

\section{2. 실험방법}

\section{1) 측정도구}

\section{(1) 시각상사척도(visual analogue scale, VAS)}

목과 어깨의 통증 정도는 대상자가 주관적으로 느끼는 통증 정도를 $10 \mathrm{~cm}$ 의 길이의 선 위에 표시하게 한 후 왼쪽 끝의 시작점에서 대상자 가 표시한 지점까지의 거리를 자로 측정하여 점수화하는 VAS를 사 용하였다. 소요시간은 1 분 미만이며 검사-재검사 신뢰도는 $\mathrm{Li}$ 등 29 의 선행연구에서 급간 내 상관계수(intraclass correlation coefficient, ICC) 가 0.70-0.83 사이였다.

\section{(2) 목통증지수(neck disability index, NDI)}

목 부위의 통증과 장애 정도를 평가하는 척도로 총 10 가지 항목(현재 통증 정도, 자기관리, 물건 들어올리기, 책 읽기, 두통, 집중력, 일하기, 운전, 잠자기, 여가활동)으로 구성되어 있으며, 각 항목은 0-5점으로 채 점된다. 0 점은 가장 가벼운 정도의 제한, 5 점은 가장 심한 정도의 제한 
이 있음을 나타내며, 총점 결과 0-4점은 "이상 없음", 5-14점은 "가벼운", 15-24점은 “중간 정도”, 25-34점은 “심한”, 35점 이상은 “심각한, 완전한” 제한이 있음을 나타낸다. 소요시간은 5-10분 사이이며 획득한 점수를 퍼센트로 변환시켜 사용한다. 이 척도의 내적 일치도는 크론바하 알파 계수(cronbach's alpha coefficient) 0.8 , 검사-재검사 신뢰도는 0.89 였다..$^{30}$

(3) 어깨통증장애지수(shoulder pain and disability index, SPADI) 어깨 부위의 통증과 장애 정도를 평가하는 평가 척도로 통증과 장애 를 측정하는 척도가 구분되어 있다. 통증 척도는 5 가지 항목(일반적 인 통증, 통증이 있는 쪽으로 누울 때, 높은 선반의 물건에 팔을 뻗을 때, 목 뒤를 잡을 때, 통증이 있는 팔로 밀 때)으로 구성되어 있으며, 통증이 없는 0 점에서 가장 심한 통증인 10 점까지 대상자가 본인의 어 깨 통증 정도를 직접 작성한다. 장애 척도는 일상 생활에서 자주 하 는 8 가지 항목(머리를 감을 때, 등을 닦을 때, 내의나 겉옷을 입을 때, 단추가 있는 셔츠를 입을 때, 바지를 입을 때, 높은 선반 위에 물건을 놓을 때, $4.5 \mathrm{~kg}$ 의 무거운 물체를 들어 나를 때, 바지 뒷주머니에서 무 엇인가를 꺼낼 때)으로 구성되어 있으며, 불편함이 전혀 없는 0점에 서 도움 없이 할 수 없는 10 점까지 대상자가 스스로 작성하여 진단이 용이하다. 소요시간은 5-10분 사이이며 채점은 통증과 장애 점수를 합산한 총점이 아니라, 통증과 장애 점수를 각각 백분위 환산한 점수 와 각 척도의 점수를 합하여 백분위로 환산한 점수를 사용한다. 크 론바하 알파 계수를 이용해 측정한 내적 일치도는 0.95 , 검사-재검사 신뢰도는 0.66 이었다. ${ }^{31}$

(4) 삶의 질 척도(36-Item short form health survey, SF-36)

환자 스스로 신체와 정신에 관련된 항목들을 통해 삶의 질(quality of Life, QoL)을 평가할 수 있는 척도로 octum에서 제공하고 있는 SF$36 \mathrm{v} 2$ 를 사용하였다. SF-36은 총 8개의 하위 영역으로 구성되어 있으 며 하위 영역들을 종합하여 신체적 영역 척도(PCS)와 정신적 영역 척 도(MCS)로 나누어 보여준다. 각각의 하위 영역은 신체적 기능(physi- cal functioning, PF), 신체적 역할(role physical, RP), 신체적 통증(bodily pain, BP), 전체적 건강 (general health, GH), 신체 활력(vitality, VT), 사회 적 기능(social functioning, $\mathrm{SF}$ ), 감정적 역할(role emotion, RE), 정신적 건강(mental health, $\mathrm{MH}$ )이다. 총 36 개의 문항으로 구성되어있으며 점 수는 0 점부터 100 점 사이이다. 점수가 높을수록 건강한 상태를 나타 내고, 점수가 낮을수록 건강하지 않고 삶에 제한이 있는 상태를 말한 다. 내적 일치도는 크론바하 알파계수 0.78-0.93 사이였다. ${ }^{32}$

\section{2) 중재방법 \\ (1) 포괄적 자세 재교육(global postural reeducation, GPR)}

GPR은 인체의 근육을 앞쪽과 뒤쪽 근육 사슬로 나누어 한 자세에서 20 분씩 한꺼번에 신장시키는 기법이다. 짧아진 근육으로 인해 GPR 중 발생할 수 있는 근육 긴장도의 항진과 이로 인해 각 관절에서 발생 할 수 있는 보상 운동을 방지하기 위해 치료사는 대상자가 운동을 하는 동안 지속적으로 관찰하며 자세를 바로 잡아주었다. 운동에 들 어가기 전, 실험 대상자에게 운동하는 동안 숨을 참지 않고 자유롭게 호흡을 하도록 교육하고 운동 중 통증이 발생하지 않는 범위에서 안 전하게 운동하도록 충분히 설명하였다.

대상자의 앞쪽 근육을 신장시키는 방법은 바로 누운 상태에서 손 바닥이 하늘을 향하도록 하고 양팔을 30 도 벌린 후 머리, 허리, 골반 을 잘 정렬시킨다. 그 후 대상자의 엉덩 관절을 굽힘, 벌림, 바깥쪽 회 전시킨 상태에서 양 발바닥을 서로 닿게 하였다. 발목 관절은 90 도로 유지하면서 발가락의 힘을 빼고 턱을 당기고 허리를 바닥에 붙인 상 태를 유지하도록 하였다. 이 상태에서 무릎을 점진적으로 끝까지 펴 게 하는데 운동이 끝나는 시점에서 양팔은 140 도까지 벌어지도록 하 였다(Figure 1A).

대상자의 뒤쪽 근육을 신장시키는 방법은 바로 누운 상태에서 천 장에 연결된 슬링에 양 다리를 걸도록 하였다. 바로 누운 자세에서 양 다리를 모으고 엉덩 관절을 90 도 굽힘하고, 양 팔은 30 도로 벌림하였 다. 머리, 허리, 골반을 잘 정렬시키고 무릎을 천천히 펴면서 팔을 벌
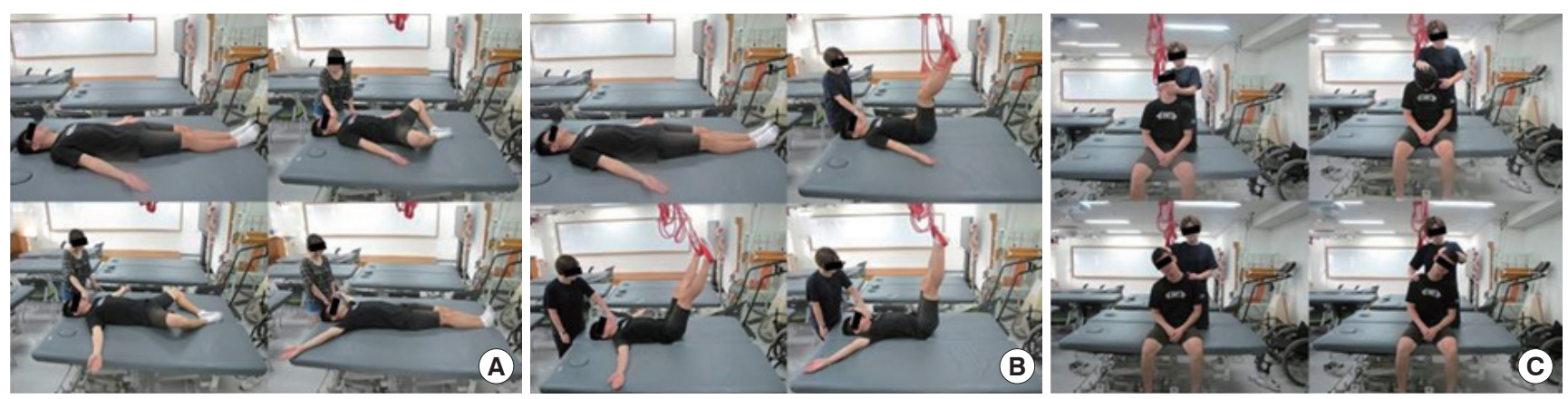

Figure 1. The global postural reeducation and segmental stretching exercise. (A) anterior muscle chain (GPR), (B) posterior muscle chain (GPR), (C) segmental stretching. 
리도록 한다. 턱을 당기고 허리를 바닥에 붙인 상태를 유지하도록 하 면서 통증이 느껴지는 범위 직전에 멈춰서 근육을 이완시킨 후 다시 진행하도록 하였다(Figure $1 \mathrm{~B}$ ). 대상자는 각 세션 동안 20 분씩 두 가지 다른 동작을 치료사의 감독하에 실시하였다.

(2) 분절적 스트레칭(segmental stretching, SS)

분절적 스트레칭은 머리와 목으로 이어지는 근육의 움직임을 구분 하여 스트레칭하였다. 대상자는 편하게 앉은 자세에서 머리, 어깨, 허 리, 골반을 잘 정렬시키도록 한 후 임상경력 5년의 치료사가 수동 스 트레칭을 실시하였다. 스트레칭 방법은 대상자의 목을 앞, 뒤, 좌, 우 로 순환하며 굽힘 운동을 실시하였고 최대 관절 가동범위에서 천천 히 숨을 내쉬며 30초간 유지하도록 하였다(Figure 1C). 최대 가동범위 는 통증이 생기지 않는 범위로 설정하였고 4 방향의 운동을 한 세트 로 하여 3 세트 실시하고, 각 세트 사이에 30초의 휴식시간을 두었다. 3 세트가 끝난 후 1 분의 휴식시간을 두어 부상을 방지하고자 하였고, 총 스트레칭 시간은 3 세트를 5 회 반복하여 약 40 분이 되도록 하였다. 치료사는 대상자의 관절 가동범위를 고려하여 스트레칭을 실시하였 고 보상 운동이 일어나지 않도록 주의하였다.

\section{3) 중재와 평가 진행절차}

중재는 임상경력 15 년 이상의 숙련된 물리치료사의 관리 감독하에 임상경력 5년 이상의 물리치료사 2명이 GPR과 분절적 스트레칭을
실시하였다. 중재 기간은 선행 연구를 참고하여 4 주 동안 주 2 회씩 총 8 회의 중재를 실시하였다. ${ }^{20}$ 중재 시간은 대상자가 원하는 시간을 정 하여 치료사와 약속하도록 하였고 1 회당 약 40 분 정도의 중재를 받았 으며 다른 대상자들이 어떤 치료를 받는지 알 수 없도록 시간 배정을 통해 눈가림(blind)하였다. 평가는 통증과 불편함, 삶의 질 측정 도구 를 사용하여 중재 전, 2주 후(4회기 중재), 4주 후(8회기 중재), 8주 후 (follow-up), 총 4 회 실시하였으며 1 회 검사는 30 분 정도 시행되었다.

\section{4) 자료 분석}

대상자의 일반적 특성과 임상 특성은 정규성 검증을 위해 ShapiroWilk 검정하였고 정규분포를 가정하는 변수는 평균과 표준편차로 나타내었고, 정규분포를 가정하지 않는 변수는 중위수와 범위로 나 타내었다. 대상자의 중재 전 일반적 특성과 임상 특성은 두 군간의 차 이를 비교하기 위해 독립 $\mathrm{t}$ 검정을 실시하였다. 중재 후 시간 경과에 따른 두 군간의 중재 효과를 검증하기 위해 이요인 반복측정 분산분 석(two-way repeated measures ANOVA)을 사용하였다. 수집된 자료는 SPSS version 23.0을 이용하여 분석하였고 통계적 유의수준 $\alpha$ 는 0.05 로 하였다.

\section{결 과}

연구 대상자의 일반적 특성과 중재 전 임상 특성은 Table 1과 같다. 일 Table 1. Baseline demographic and clinical characteristics of participants

\begin{tabular}{|c|c|c|c|c|c|c|c|}
\hline \multirow{2}{*}{ Variables } & & \multicolumn{2}{|c|}{ GPR group $(n=8)$} & \multicolumn{2}{|c|}{ SS group $(n=8)$} & \multirow{2}{*}{ t-value } & \multirow{2}{*}{$\mathrm{p}$-value } \\
\hline & & Mean & SD & Mean & SD & & \\
\hline Age & & 24.25 & 3.69 & 25.88 & 4.82 & -0.76 & 0.46 \\
\hline Height & & 169.75 & 8.28 & 170.13 & 10.18 & -0.08 & 0.94 \\
\hline Weight & & 56.25 & 10.55 & 62.88 & 11.72 & -1.19 & 0.25 \\
\hline VAS & & 5.26 & 1.76 & 5.95 & 1.41 & -0.86 & 0.40 \\
\hline NDI & & 10.38 & 5.78 & 6.88 & 2.80 & 1.54 & 0.15 \\
\hline \multirow[t]{3}{*}{ SPADI } & Pain & 32.75 & 25.59 & 39.25 & 22.63 & -0.54 & 0.60 \\
\hline & Disability & 4.38 & 10.94 & 1.56 & 2.89 & 0.70 & 0.49 \\
\hline & Total & 20.87 & 18.73 & 22.21 & 17.09 & -0.15 & 0.88 \\
\hline \multirow[t]{10}{*}{ SF-36 } & PCS & 43.98 & 5.77 & 46.98 & 6.43 & -0.98 & 0.34 \\
\hline & MCS & 39.73 & 9.68 & 36.96 & 12.33 & 0.50 & 0.63 \\
\hline & Physical functioning & 48.78 & 3.85 & 54.23 & 3.32 & -3.03 & 0.01 \\
\hline & Role physical & 44.76 & 9.20 & 46.51 & 7.49 & -0.42 & 0.68 \\
\hline & Bodily pain & 41.13 & 8.45 & 38.34 & 6.28 & 0.75 & 0.47 \\
\hline & General health & 40.00 & 9.06 & 43.05 & 9.47 & -0.66 & 0.52 \\
\hline & Vitality & 45.51 & 6.57 & 41.38 & 6.66 & 1.25 & 0.23 \\
\hline & Social functioning & 38.15 & 8.21 & 37.48 & 8.17 & 0.17 & 0.87 \\
\hline & Role emotional & 40.83 & 14.83 & 42.14 & 15.67 & -0.17 & 0.87 \\
\hline & Mental health & 40.49 & 9.40 & 38.80 & 8.87 & 0.37 & 0.72 \\
\hline
\end{tabular}

GPR: global postural reeducation, SS: segmental stretching, SD: standard deviation, VAS: visual analogue scale, NDI: neck disability index, SPADI: shoulder pain disability index, PCS: physical component scale, MCS: mental component scale. 
반적 특성인 나이와 키, 몸무게는 두 군간의 차이가 없었고 임상 특성 에서도 SF-36의 신체적 기능을 제외하고는 중재 전 측정값의 차이가 없어 두 군의 특성은 동일하다고 할 수 있다 $(\mathrm{p}>0.05)$.
본 연구의 주요 결과는 Table 2와 Figures 2, 3에 나타내었다. 먼저, 통증 정도(VAS)는 이요인 반복측정 ANOVA 결과 중재 후 시간 경과 와 중재 군 간의 상호작용이 존재하였고 $(\mathrm{F}=10.31, \mathrm{p}<0.05), \mathrm{GPR}$ 군이

Table 2. Comparison between the GPR and SS group at pre- and post-intervention evaluations

\begin{tabular}{|c|c|c|c|c|c|c|c|c|c|}
\hline \multirow{3}{*}{ Variables } & & \multicolumn{4}{|c|}{ GPR group $(n=8)$} & \multicolumn{4}{|c|}{ SS group $(n=8)$} \\
\hline & & \multicolumn{4}{|c|}{ Mean $\pm S D$} & \multicolumn{4}{|c|}{ Mean $\pm S D$} \\
\hline & & pre & Post1 & Post2 & Post3 & pre & Post1 & Post2 & Post3 \\
\hline \multicolumn{2}{|l|}{ VAS } & $5.26 \pm 1.76$ & $3.66 \pm 1.21$ & $2.76 \pm 1.70$ & $2.71 \pm 2.30$ & $5.95 \pm 1.41$ & $4.23 \pm 1.44$ & $4.13 \pm 1.64$ & $5.89 \pm 1.32$ \\
\hline \multicolumn{2}{|l|}{ NDI } & $10.38 \pm 5.78$ & $9.13 \pm 6.13$ & $6.25 \pm 4.62$ & $6.13 \pm 4.58$ & $6.88 \pm 2.80$ & $3.50 \pm 2.67$ & $4.63 \pm 3.16$ & $7.13 \pm 2.95$ \\
\hline \multirow[t]{3}{*}{ SPADI } & Pain & $32.75 \pm 25.59$ & $28.50 \pm 29.10$ & $23.00 \pm 29.30$ & $19.25 \pm 23.66$ & $39.25 \pm 22.63$ & $28.50 \pm 14.57$ & $31.25 \pm 19.18$ & $45.75 \pm 12.80$ \\
\hline & Disability & $4.38 \pm 10.94$ & $9.38 \pm 26.52$ & $4.84 \pm 9.48$ & $7.81 \pm 10.79$ & $1.56 \pm 2.89$ & $3.59 \pm 7.33$ & $3.59 \pm 7.24$ & $15.63 \pm 9.23$ \\
\hline & Total & $20.87 \pm 18.73$ & $21.92 \pm 27.37$ & $14.13 \pm 18.31$ & $12.21 \pm 15.54$ & $22.21 \pm 17.09$ & $15.29 \pm 7.43$ & $16.15 \pm 9.00$ & $27.21 \pm 9.42$ \\
\hline \multirow[t]{10}{*}{ SF-36 } & PCS & $43.98 \pm 5.77$ & $43.69 \pm 6.94$ & $49.19 \pm 5.43$ & $49.16 \pm 4.89$ & $46.98 \pm 6.43$ & $50.15 \pm 6.34$ & $52.05 \pm 3.13$ & $49.61 \pm 3.74$ \\
\hline & MCS & $39.73 \pm 9.68$ & $43.15 \pm 10.67$ & $42.16 \pm 10.30$ & $42.98 \pm 8.83$ & $36.96 \pm 12.33$ & $40.64 \pm 9.83$ & $40.54 \pm 10.05$ & $38.21 \pm 10.44$ \\
\hline & Physical functioning & $48.78 \pm 3.85$ & $47.49 \pm 3.71$ & $50.60 \pm 3.42$ & $51.86 \pm 2.53$ & $54.23 \pm 3.32$ & $55.54 \pm 2.14$ & $55.16 \pm 2.59$ & $54.49 \pm 2.66$ \\
\hline & Role physical & $44.76 \pm 9.20$ & $47.48 \pm 7.34$ & $50.91 \pm 8.23$ & $51.43 \pm 7.68$ & $46.51 \pm 7.49$ & $47.39 \pm 9.06$ & $50.05 \pm 5.88$ & $50.79 \pm 6.09$ \\
\hline & Bodily pain & $41.13 \pm 8.45$ & $41.23 \pm 9.03$ & $45.19 \pm 7.73$ & $45.15 \pm 7.73$ & $38.34 \pm 6.28$ & $47.06 \pm 7.60$ & $49.10 \pm 6.55$ & $45.01 \pm 7.76$ \\
\hline & General health & $40.00 \pm 9.06$ & $41.11 \pm 13.12$ & $46.74 \pm 11.76$ & $45.50 \pm 10.53$ & $43.05 \pm 9.47$ & $44.56 \pm 9.15$ & $46.25 \pm 8.05$ & $43.86 \pm 8.56$ \\
\hline & Vitality & $45.51 \pm 6.57$ & $45.53 \pm 9.03$ & $48.48 \pm 6.17$ & $48.30 \pm 5.17$ & $41.38 \pm 6.66$ & $44.34 \pm 5.79$ & $45.21 \pm 5.34$ & $42.88 \pm 5.22$ \\
\hline & Social functioning & $38.15 \pm 8.21$ & $42.90 \pm 5.76$ & $42.90 \pm 5.76$ & $43.58 \pm 5.27$ & $37.48 \pm 8.17$ & $45.61 \pm 7.89$ & $44.93 \pm 8.57$ & $40.15 \pm 5.22$ \\
\hline & Role emotional & $40.83 \pm 14.83$ & $43.46 \pm 14.28$ & $43.46 \pm 14.28$ & $44.48 \pm 14.27$ & $42.14 \pm 15.67$ & $42.15 \pm 13.50$ & $44.78 \pm 13.79$ & $42.98 \pm 12.82$ \\
\hline & Mental health & $40.49 \pm 9.40$ & $42.79 \pm 8.66$ & $42.76 \pm 9.94$ & $43.54 \pm 8.62$ & $38.80 \pm 8.87$ & $43.06 \pm 7.57$ & $41.65 \pm 7.81$ & $39.65 \pm 6.95$ \\
\hline
\end{tabular}

GPR: global postural reeducation, SS: segmental stretching, SD: standard deviation, VAS: visual analogue scale, NDI: neck disability index, SPADI: shoulder pain disability index, PCS: physical component scale, MCS: mental component scale.
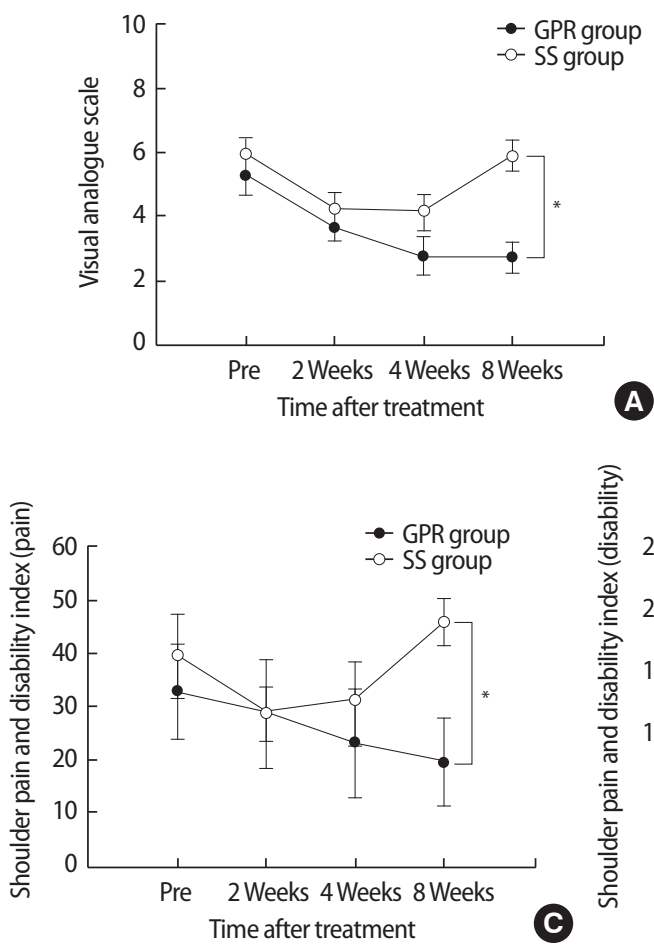
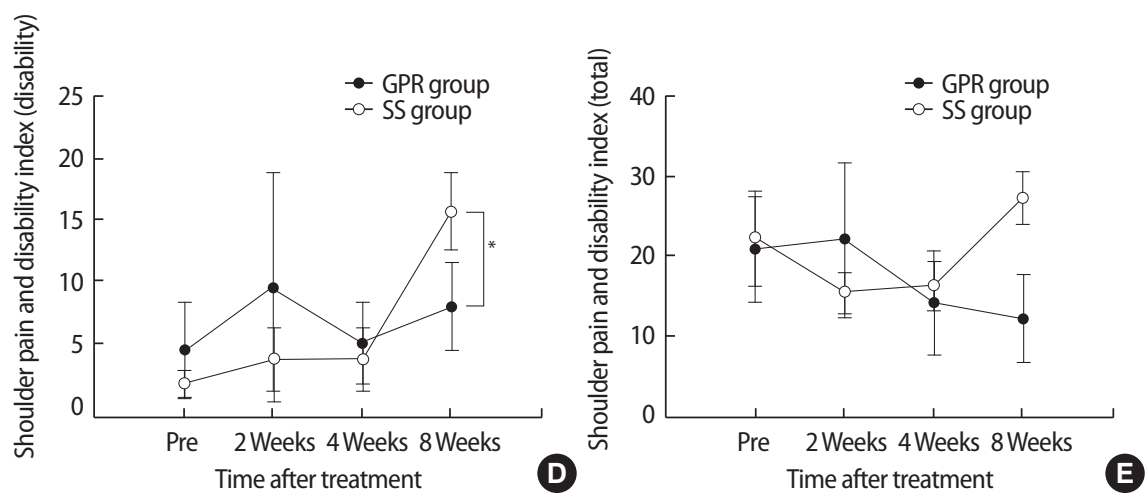

Figure 2. Comparison between the GPR and SS group of VAS and NDI, SPADI. (A) VAS: visual analogue scale, (B) NDI: neck disability index, (C) SPADI: shoulder pain and disability index (pain), (D) SPADI (disability), (E) SPADI (total). 

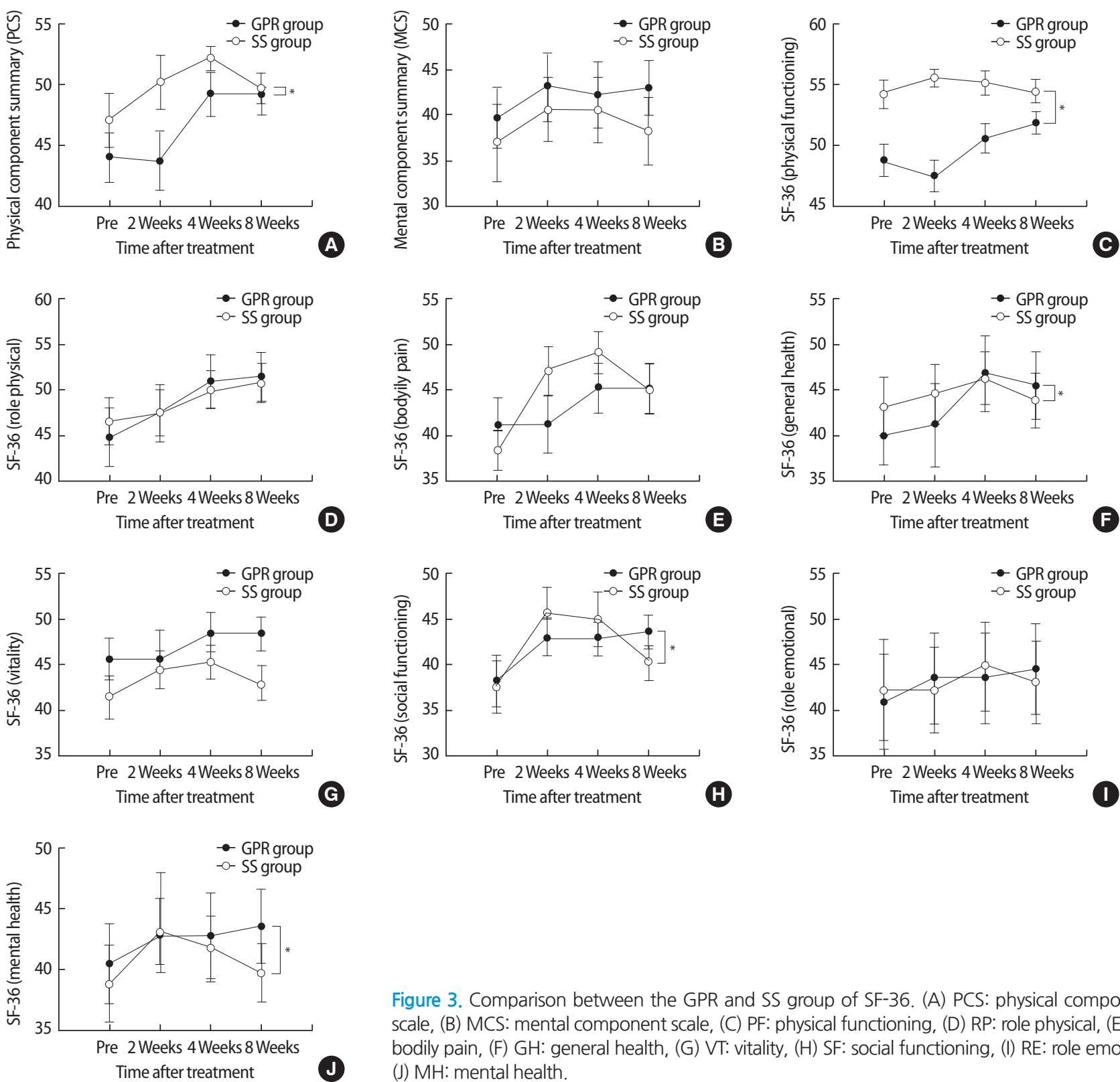

Figure 3. Comparison between the GPR and SS group of SF-36. (A) PCS: physical component scale, (B) MCS: mental component scale, (C) PF: physical functioning, (D) RP: role physical, (E) BP: bodily pain, (F) GH: general health, (G) VT: vitality, (H) SF: social functioning, (I) RE: role emotion, (J) $\mathrm{MH}$ : mental health.

SS군에 비해 시간이 경과하면서 통증이 더 많이 감소하였다(Table 2, Figure $2 \mathrm{~A})$. 목의 장애 정도(NDI)는 중재 후 시간 경과와 중재 군간의 상호작용이 존재하였고 $(\mathrm{F}=25.45, \mathrm{p}<0.05), \mathrm{GPR}$ 군이 $\mathrm{SS}$ 군에 비해 시 간이 경과하면서 목의 장애 정도가 더 많이 감소하였다(Table 2, Figure $2 \mathrm{~B})$. 어깨의 장애 정도(SPADI)에서 통증과 총점은 중재 후 시간 경 과와 중재 군간의 상호작용이 존재하였고(pain $\mathrm{F}=14.55, \mathrm{p}<0.05$, total $\mathrm{F}=12.82, \mathrm{p}<0.05), \mathrm{GPR}$ 군이 SS군에 비해 시간이 경과하면서 어깨의 통증과 장애 정도가 더 많이 감소하였다(Table 2, Figure 2C, E). 어깨 장애 정도에서 장애는 시간과 군간의 상호작용이 존재하지 않았고 $(\mathrm{F}=1.60, \mathrm{p}>0.05)$, 따라서, 각 요인의 주 효과를 따로 분석한 결과 시간 경과에 따라 두 군 모두 장애 정도가 감소하다가 증가하였는데 두 군
간의 차이는 나타나지 않았다( $>$ > 0.05) (Table 2, Figure 2D). 삶의 질을 측정한 결과 신체적 영역 척도(PCS)는 중재 후 시간 경 과와 군간의 상호작용이 존재하였고 $(\mathrm{F}=4.85, \mathrm{p}<0.05), \mathrm{GPR}$ 군이 SS군 에 비해 PCS 값이 낮았으나 시간이 경과하면서 SS군과 비슷한 정도 로 높아졌다 $(\mathrm{p}<0.05)$ (Table 2, Figure $3 \mathrm{~A})$. 정신적 영역 척도 $(\mathrm{MCS})$ 는 중재 후 시간과 군간의 상호작용이 존재하지 않았고 $(\mathrm{F}=3.46, \mathrm{p}>0.05)$, 주효과를 분석하였을 때 GPR군에서 시간이 경과하면서 MCS 값이 증가하였으나 통계적으로 유의하지는 않았다(p>0.05) (Table 2, Figure $3 \mathrm{~B}$ ). 삶의 질 측정의 세부 항목들을 분석한 결과 신체적 기능(PF), 전체적 건강 $(\mathrm{GH})$, 사회적 기능 $(\mathrm{SF})$, 정신적 건강 $(\mathrm{MH})$ 은 중재 후 시간 경과와 군간의 상호작용이 존재하였고 $(\mathrm{p}<0.05)$ 중재에 따라 $\mathrm{GPR}$ 군 
에서 시간이 경과하면서 삶의 질이 증가하였다(Table 2, Figure 3C, F, $\mathrm{H}, \mathrm{J})$. 삶의 질 세부 항목들 중 신체적 역할(RP), 신체적 통증(BP), 신체 활력(VT), 감정적 역할(RE)은 시간 경과와 중재 군간의 상호작용이 존재하지 않아 주효과를 분석하였을 때 RP와 $\mathrm{BP}$ 는 주효과 중 시간 경과에 따라삶의 질이 증가하였으나 $(\mathrm{p}<0.05)$ 중재 군간의 차이는 통 계적으로 유의하지 않았다(Table 2, Figure 3D, E). VT와 RE는 시간 경 과에 따른 차이와 중재 군간의 차이가 모두 존재하지 않았다(Table 2, Figure 3G, I).

\section{고 찰}

본 연구는 목과 어깨에 통증과 불편함을 호소하는 사람을 대상으로 새로운 스트레칭 기법인 GPR과 기본적인 스트레칭 기법인 SS 를 적 용하여 통증과 장애, 삶의 질에 차이가 있는지 알아보았다. 그 결과 목과 어깨의 통증과 장애 정도는 GPR군이 SS군에 비해 시간이 경과 함에 따라 더 많이 감소하였고 $(\mathrm{p}<0.05)$ 추적관찰 시에도 감소 정도 가 더 잘 유지되었다. 삶의 질은 신체 영역에서는 GPR군이 SS군에 비 해 시간 경과에 따라 더 많이 증가하였고 통계적으로 유의하였으나 정신 영역은 삶의 질 증가가 통계적으로 유의하지 않았다.

GPR은 프랑스 Philippe-Emmanuel Souchard에 의해 개발되어 브라 질과 프랑스, 이탈리아 등 유럽에서 주로 사용하고 있는 물리치료 기 법이다. ${ }^{23} \mathrm{GPR}$ 은 근육사슬을 한번에 스트레칭하는 방법으로 목과 허 리 통증 외에도 턱관절 통증, 경직성 척추염, 요실금 환자에게 효과적 인 결과를 나타내었으며 최근에는 자세 불균형에도 효과가 있는 것 으로 보고되고 있다. ${ }^{20,22-25,33}$

본 연구에서는 목과 어깨 통증이 있는 대상자에게 GPR이 기존의 분절적 스트레칭보다 효과적인 것으로 나타났다. 총 8 회기의 GPR 중 재 후 통증 정도는 $5.26 \mathrm{~cm}$ 에서 $2.76 \mathrm{~cm}$ 로 감소하였고 이에 반해 $\mathrm{SS}$ 군 에서는 $5.95 \mathrm{~cm}$ 에서 $4.13 \mathrm{~cm}$ 로 통증이 감소하였다. 중재가 끝나고 4 주 후 추적 관찰한 결과, $\mathrm{GPR}$ 군은 $2.71 \mathrm{~cm}$ 로 통증이 감소된 상태를 유지 하고 있었고 $\mathrm{SS}$ 군은 $5.89 \mathrm{~cm}$ 로 통증이 다시 증가하였다. 목 통증과 어 깨뼈 운동이상(scapular dyskinesis)을 동반한 환자를 대상으로 10 주 간 주 1 회의 중재를 실시하고 단기 결과를 비교한 Amorim 등 23 의 연 구에서는 GPR군이 SS군에 비해 현저한 통증감소를 나타내었고 두 군간의 유의한 차이가 있었다고 $(\mathrm{p}=0.003)$ 보고하여 본 연구의 결과 와 일치하였다. 요통 환자를 대상으로 5 주간 주 2 회의 중재를 실시하 고 3 개월, 6 개월에 추적 관찰한 Bonetti 등 24 의 연구 결과, 본 연구 결과 와 같이 GPR군이 SS군에 비해 통증이 더 많이 감소하였고 추적관찰 시에도 통증 감소가 잘 유지되었다. 턱관절 통증에 8 주간 주 1 회 중재 를 실시하고 중재 직후와 8 주 중재 후 통증 감소를 확인한 Maluf 등 20 의 연구는 본 연구의 연구방법과 가장 유사하였고 GPR군은 점차 통
증이 감소한 반면 SS군은 통증이 감소하다가 증가하였으나 본 연구 와는 달리 군간의 통계적인 차이가 나타나지 않았다. Lawand 등 25 은 만성 요통 환자에게 GPR과 약물 치료를 수행하고 비교한 결과 GPR 군에서만 유의한 통증 감소 효과가 있었고 약물은 통증 감소를 일으 키지 않았음을 보고하였다. 본 연구와 유사한 선행 연구 결과들을 종 합해 볼 때, GPR은 목과 어깨의 통증 감소에 효과적인 스트레칭 기법 이라 할 수 있으며 기존의 분절적 스트레칭에 비해 통증 감소와 중재 후 유지가잘되는 것을 알 수 있었다. 이러한 유지 효과는 GPR 기법이 하나의 근육이나 동작을 스트레칭하는 것이 아니라 근육사슬을 이 용하여 전체적인 근육의 길이와 수축력에 영향을 미치기 때문이라 고 생각된다. GPR 기법과 유사하게 여러 근육을 하나의 패턴으로 연 결하여 스트레칭하는 PNF의 경우에도 분절적 스트레칭에 비해 통 증과 유연성 증진에 효과적이라고 주장하는 근거들이 있다. ${ }^{34,35}$ 따라 서 기존의 스트레칭 방법이나 약물치료 외에 다른 중재 기법을 모색 하고 있는 치료사들에게 GPR은 새로운 중재가 될 수 있으리라 생각 한다.

또 하나의 중요한 결과는 삶의 질 부분이다. 삶의 질은 건강과 장애 분류가 변화함에 따라 근거중심 물리치료 분야에서도 중요한 결과 변수로 적용되고 있는 지표이다. 본 연구자들의 이전 선행연구에서 는 목과 어깨의 통증과 장애, 삶의 질 관련성을 살펴본 결과 통증과 장애 정도는 양의 상관관계를 나타내었고, 통증과 장애는 삶의 질 중 신체영역과 음의 상관관계를 나타내었다. ${ }^{36}$ 본 연구는 GPR군이 SS군 에 비해 삶의 질 척도가 통계적으로 유의하게 증가하였다. 그 중에서 도 신체 영역은 중재 후 시간 경과에 따라 두 군의 삶의 질 증가에 차 이가 있었으나 정신 영역에서는 두 군 간의 상호작용이 나타나지 않 았다. GPR을 중재하고 통증과 삶의 질을 함께 비교한 연구들을 살펴 보면 Amorim 등 23 은 10 주간 중재 후 SF-12를 이용하여 GPR과 SS를 비교한 결과 삶의 질 영역 중 신체 영역에서 GPR군이 SS군에 비해 삶 의 질이 증가하였다 $(\mathrm{p}=0.049)$. Cunha 등22은 만성 목통증이 있는 여 성 31명을 대상으로 6주간 주 2회씩 GPR과 SS를 시행하였고 삶의 질 을 SF-36의 8개 하위 영역으로 나누어 비교하였는데, 그 결과 GPR군 과 $\mathrm{SS}$ 군 모두 삶의 질 하위 영역이 중재 후 증가하였으나 두 군 간의 차이는 없었다고 보고하였다. 본 연구와 Cunha 등22의 연구는 모두 목통증이 있는 사람을 대상으로 하였으나 중재 방법에 차이가 있었 다. 본 연구는 GPR과 SS 각기 다른 중재 방법만을 적용하였으나 Chunha 등 22 은 GPR과 SS 전 30분간 동일한 도수치료(호흡을 비롯한 목과 어깨 근막의 스트레칭과 이완 기법)를 적용하였다. 이러한 중재 기법의 차이로 인해 본 연구에서는 GPR이 SS에 비해 좋은 결과를 나 타내었으나 동일한 중재를 두 군 모두 적용한 후 GPR과 SS를 적용한 선행 연구에서는 두 군 간의 차이가 없었던 것으로 생각된다. 그 외에 도 강직성 척추염 환자에게 GPR (주 1회 60분)과 자가 스트레칭(주 2 
회 40 분)을 16 주간 중재한 후 비교한 선행 연구에서는 두 군 모두 중 재 후 목통증이 감소하였으나 두 군 간의 차이는 유의하지 않았고 $(\mathrm{p}=0.27), \mathrm{SF}-36$ 을 이용해 측정한 삶의 질은 두 군 모두 신체 영역과 정신 영역에서 중재 후 삶의 질이 증가하였으나 두 군 간의 차이는 본 연구와 같이 신체 영역에서만 나타났다(PCS p $=0.00, \mathrm{MCS} p=0.82){ }^{28}$ 따라서, 본 연구의 결과에서 나타난 삶의 질 증진은 통증과 장애 정 도의 감소에 따른 효과라고 설명할 수 있으며 GPR군이 SS군에 비해 삶의 질 증가가 나타나 GPR은 목과 어깨의 통증이 있는 대상자의 삶 의 질에 긍정적인 영향을 미치는 것으로 사료된다.

마지막으로 비교할 부분은 목과 어깨의 장애 정도에 대한 지표인 목통증지수(NDI)와 어깨통증장애지수(SPADI)의 결과이다. GPR과 관련한 현재까지의 연구 결과들은 많지 않으며 그 중에서도 목과 어 깨의 통증과 불편함에 대한 연구는 단 3 편뿐이다. $22,23,37$ 목통증지수 가 보고된 Amorim 등 23 의 연구에서는 $\mathrm{GPR}$ 군이 $\mathrm{SS}$ 군에 비해 목의 불 편함이 감소하였으나 $(\mathrm{p}=0.23)$ 두 군 간의 차이는 없었다 $(\mathrm{p}=0.134)$. 최 근의 다른 연구에서는 GPR군의 목통증지수가 1회 중재 후 낮아졌다 가 6개월 후 추적 관찰 시 다시 증가하였으나 대조군인 도수치료군에 비해 효과적이었다고 보고하였다. ${ }^{37}$ 본 연구에서는 목통증지수도 통 증과 마찬가지로 GPR군에서는 중재 후 추적 관찰까지 지속적으로 감소하였고 SS군은 중재 후 감소하였다가 추적 관찰 시 다시 증가하 였고 두 군간의 차이가 존재하였다 $(\mathrm{p}<0.05)$. 선행연구와의 차이는 본 연구의 대상자가 가진 특성 때문인 것으로 사료된다. 본 연구의 대상 자는 목과 어깨의 통증과 불편감을 자가 호소한 대상자로 20대였고, 중재 전 초기 값이 선행 연구에 비해 12-18점 정도 낮았다. 그에 비해 선행 연구는 3 개월 이상 만성 목통증을 호소하고 어깨의 운동이상 을 나타내는 환자를 대상으로 하였으며 나이가 40 대로 본 연구의 대 상자보다 훨씬 연장자들로 구성되었다. 이 같은 대상자의 차이에 의 해 본 연구에서는 젊고 건강한 대상자들을 모집하여 변화가 더 빠르 고 크게 나타난 반면 Amorim 등 23 의 결과에서는 변화가 적었던 것으 로 생각된다. 이와 같은 결과를 바탕으로 $\mathrm{GPR}$ 은 젊은 연령에서 많이 증가하고 있는 목과 어깨의 불편함을 해소하는 데도 적절한 중재 방 법 중 하나로 사용하기에 충분하다고 사료된다.

본 연구는 무작위 배정 임상시험의 장점을 최대한 살리고자 무작 위 배정과 대상자 눈가림 설계를 통해 결과의 비뚤림을 줄이려고 노 력하였다. 그럼에도 불구하고 대상자의 표본 크기가 작았고, 대상자 가 목과 어깨의 통증과 장애로 진단받은 환자가 아니어서 모집단인 목과 어깨 통증이 있는 환자 전체로 일반화하기에는 어려움이 있다. 앞으로 물리치료 분야에서도 이러한 제한점을 보완한 질 높은 무작 위 배정 임상시험 연구가 많이 이루어지길 기대한다. 본 연구는 목과 어깨의 통증과 불편함을 호소하는 대상자에게 일정한 자세를 교육 하여 근육 사슬을 전체적으로 스트레칭하는 새로운 GPR 기법을 소
개하였다. 본 연구의 결과가 목과 어깨의 통증과 장애를 감소시키고 삶의 질을 증진시키기 위한 중재 방법을 선택하는 데 도움이 되길 바 라며, 물리치료사의 임상문제해결을 위해 다양한 중재 기법을 파악 하고 효과적인 결과를 얻을 수 있는 근거가 되기를 기대한다. 또한 근 육사슬을 이용한 PNF와 비교하거나 다른 중재 방법과 비교하여 $\mathrm{GPR}$ 이 적절한 중재방법인지 확인할 필요가 있다고 생각한다. 앞으로 점차 증가하고 있는 목과 어깨의 통증과 불편함을 해소할 수 있는 적 절한 운동 방법을 선택하고 중재하는 물리치료사들에게 좋은 근거 가 마련되기를 바라며 그 근거들을 바탕으로 한 적절한 지침서가 발 행될 수 있기를 바란다.

\section{감사의 글}

본 연구가 이루어질수 있도록 도와주신 고려대학교 물리치료학과 김 준선 교수님께 감사의 말씀을 전합니다.

\section{참고문헌}

1. Edmondston SJ, Wallumrød ME, MacLéid F et al. Reliability of isometric muscle endurance tests in subjects with postural neck pain. J Manipulative Physiol Ther. 2008;31(5):348-54.

2. Walker-Bone K, Cooper C. Hard work never hurt anyone: Or did it? A review of occupational associations with soft tissue musculoskeletal disorders of the neck and upper limb. Ann Rheum Dis. 2005;64(10):1391-6.

3. Kong YS, Kim YM, Shim JM. Effects of modified cervical exercise on respiratory functions in smartphone users with forward head posture. J Kor Phys Ther. 2016;28(5):292-6.

4. Lv P, Peng Y, Zhang Y et al. Kinematic causes and exercise rehabilitations of patients with round shoulder, thoracic kyphosis and forward head posture (fhp). Epidemiology: Open Access. 2016;6(5):1-6.

5. Lee HJ. Neck pain and functioning in daily activities associated with smartphone usage. J Kor Phys Ther. 2016;28(3):183-8.

6. Tunwattanapong P, Kongkasuwan R, Kuptniratsaikul V. The effectiveness of a neck and shoulder stretching exercise program among office workers with neck pain: a randomized controlled trial. Clin Rehabil. 2016;30:64-72.

7. Garra G, Singer AJ, Leno R et al. Heat or cold packs for neck and back strain: a randomized controlled trial of efficacy. Acad Emerg Med. 2010; 17(5):484-9.

8. Gross A, Miller J, D’Sylva J et al. Manipulation or mobilisation for neck pain: a cochrane review. Man Ther. 2010;15(4):315-33.

9. Chow RT, Johnson MI, Lopes-Martins RA et al. Efficacy of low-level laser therapy in the management of neck pain: a systematic review and meta-analysis of randomised placebo or active-treatment controlled trials. Lancet. 2009;374(9705):1897-908.

10. Ylinen J. Physical exercises and functional rehabilitation for the management of chronic neck pain. Eura Medicophys. 2007;43:119.

11. Kisner C, Colby LA. Therapeutic exercise: foundations and techniques. 
Fa Davis, 2012:73-6.

12. Shrier I. Stretching before exercise does not reduce the risk of local muscle injury: a critical review of the clinical and basic science literature. Clin J Sport Med. 1999;9(4):221-7.

13. Malliaropoulos N, Papalexandris S, Papalada A et al. The role of stretching in rehabilitation of hamstring injuries: 80 athletes follow-up. Med Sci Sports Exerc. 2004;36(5):756-9.

14. Chon SC, Chang KY. The effects of post-isometric contraction stretching combined with antagonist muscle contraction on muscle strength and flexibility. Journal of Sport and Leisure Studies. 2010;40(2):709-17.

15. Areeudomwong P, Wongrat W, Neammesri N et al. A randomized controlled trial on the long-term effects of proprioceptive neuromuscular facilitation training, on pain-related outcomes and back muscle activity, in patients with chronic low back pain. Musculoskeletal Care. 2016.

16. Teodori RM, Negri JR, Cruz MC et al. Global postural re-education: a literature review. Rev Bras Fisioter. 2011;15(3):185-9.

17. Andersson HI. The epidemiology of chronic pain in a swedish rural area. Qual Life Res. 1994;3:S19-S26.

18. Costa LO, Maher CG, Latimer J et al. Motor control exercise for chronic low back pain: a randomized placebo-controlled trial. Phys Ther. 2009; 89(12):1275-86.

19. Tsatsouline P. Relax into stretch: instant flexibility through mastering muscle tension. Dragon Door Publication, 2001:39-44.

20. MalufSA, Moreno BG, Crivello O et al. Global postural reeducation and static stretching exercises in the treatment of myogenic temporomandibular disorders: a randomized study. J Manipulative Physiol Ther. 2010;33(7):500-7.

21. Fozzatti C, Herrmann V, Palma T et al. Global postural re-education: an alternative approach for stress urinary incontinence? E Eur J Obstet Gynecol Reprod Biol. 2010;152(2):218-24.

22. Cunha ACV, Burke TN, França FJR et al. Effect of global posture reeducation and of static stretching on pain, range of motion, and quality of life in women with chronic neck pain: a randomized clinical trial. Clinics. 2008;63(6):763-70.

23. Amorim CS, Gracitelli ME, Marques AP et al. Effectiveness of global postural reeducation compared to segmental exercises on function, pain, and quality of life of patients with scapular dyskinesis associated with neck pain: a preliminary clinical trial. J Manipulative Physiol Ther. 2014;37(6):441-7.

24. Bonetti F, Curti S, Mattioli S et al. Effectiveness of a'global postural reeducation'program for persistent low back pain: a non-randomized con- trolled trial. BMC Musculoskelet Disord. 2010;11:1.

25. Lawand P, Júnior IL, Jones A et al. Effect of a muscle stretching program using the global postural reeducation method for patients with chronic low back pain: a randomized controlled trial. Joint Bone Spine. 2015; 82(4):272-7.

26. Fozzatti MC, Palma P, Herrmann V et al. Impact of global postural reeducation for treatment of female stress urinary incontinence. Rev Assoc Med Bras. 2008;54:17-22.

27. Ferreira GE, Barreto RG, Robinson CC et al. Global postural reeducation for patients with musculoskeletal conditions: a systematic review of randomized controlled trials. Braz J Phys Ther. 2016(AHEAD);20(3): 194-205.

28. Silva EM, Andrade SC, Vilar MJ. Evaluation of the effects of global postural reeducation in patients with ankylosing spondylitis. Rheumatol Int. 2012;32(7):2155-63.

29. Li L, Liu X, Herr K. Postoperative pain intensity assessment: a comparison of four scales in chinese adults. Pain Med. 2007;8(3):223-34.

30. Vernon H. The neck disability index: sate-of-the-art, 1991-2008. J Manipulative Physiol Ther. 2008;31(7):491-502.

31. Roach KE, Budiman-Mak E, Songsiridej N et al. Development of a shoulder pain and disability index. Arthritis Rheum. 1991;4(4):143-9.

32. McHorney CA, Ware Jr JE, Raczek AE. The mos 36-item short-form health survey (sf-36): li. psychometric and clinical tests of validity in measuring physical and mental health constructs. Med Care. 1993;31(3): 247-63.

33. Dimitrova E, Rohleva M. Global postural reeducation in the treatment of postural impairments. Res Kinesiology. 2014;4:72-5.

34. Minshull C, Eston R, Bailey A et al. The differential effects of pnf versus passive stretch conditioning on neuromuscular performance. Eur J Sport Sci. 2014;14(3):233-41.

35. Yildirim MS, Ozyurek S, Tosun O et al. Comparison of effects of static, proprioceptive neuromuscular facilitation and mulligan stretching on hip flexion range of motion: a andomized controlled trial. Biol Sport. 2016;33:89-94.

36. Jeon HC, Yang KW, Kim KH et al. Relationship of pain, disability and quality of life in individual with neck and shoulder pain. J Kor Phys Ther. 2016;28(5):328-33.

37. Pillastrini P, Banchelli F, Burioli A et al. Effectiveness of global postural re-education in patients with chronic nonspecific neck pain: randomized controlled trial. Phys Ther. 2016;96(9):1408-16. 